\title{
An empirical remote sensing algorithm for retrieving total suspended matter in a large estuarine region
}

\author{
Martina D. Camiolo 1,2,3, Ezequiel Cozzolino ${ }^{2}$, Ana I. Dogliotti ${ }^{3,4,6}$, Claudia G. Simionato ${ }^{5,6,7}$, \\ Carlos A. Lasta ${ }^{2}$ \\ ${ }^{1}$ Universidad Provincial del Sudoeste (UPSO), subsede Coronel Pringles, Buenos Aires, Argentina. \\ (MDC) (Corresponding author) E-mail: dcamiolo@inidep.edu.ar. ORCID iD: https://orcid.org/0000-0002-3754-869X \\ ${ }^{2}$ Subprograma de Sensoramiento Remoto, Instituto Nacional de Investigación y Desarrollo Pesquero (INIDEP). \\ (EC) E-mail: ecozzolino@inidep.edu.ar. ORCID iD: https://orcid.org/0000-0003-3693-3702 \\ (CAL) E-mail: clasta@inidep.edu.ar. ORCID iD: https://orcid.org/0000-0002-7154-7084 \\ ${ }^{3}$ Consejo Nacional de Investigaciones Científicas y Técnicas (CONICET). \\ (AID) E-mail: adogliotti@gmail.com. ORCID iD: https://orcid.org/0000-0001-8834-4374 \\ ${ }^{4}$ Instituto de Astronomía y Física del Espacio (IAFE), CONICET, Universidad de Buenos Aires, Facultad de Ciencias \\ Exactas y Naturales, Buenos Aires, Argentina. \\ ${ }^{5}$ Centro de Investigaciones del Mar y la Atmósfera (CIMA/CONICET/UBA), Buenos Aires, Argentina. \\ (CGS) E-mail: simionato@ cima.fcen.uba.ar. ORCID iD: https://orcid.org/0000-0002-6108-037X \\ ${ }^{6}$ Instituto Franco-Argentino para el Estudio del Clima y sus Impactos (UMI/IFAECI/CNRS/CONICET/UBA), \\ Buenos Aires, Argentina. \\ ${ }^{7}$ Departamento de Ciencias de la Atmósfera y los Océanos, FCEN, Universidad de Buenos Aires, Argentina.
}

\begin{abstract}
Summary: The Río de la Plata is a large, shallow estuary located at approximately $35^{\circ} \mathrm{S}$ and flowing into the southwestern Atlantic Ocean. It carries a high amount of nutrients and suspended particulate matter, both organic and inorganic, to the adjacent shelf waters and is considered among the most turbid estuarine systems in the world. Knowledge of the concentration and spatial and temporal variability of these materials is critical for any biological study in the Río de la Plata. In this work, the relationship between suspended particulate matter and turbidity is empirically established in order to derive suspended particulate matter maps from satellite data (MODIS-Aqua) for the Río de la Plata region. A strong correlation between suspended particulate matter and turbidity was found (Pearson correlation coefficient $=0.91$ ) and the linear regression (slope $=0.76$ and intercepts $=12.78, \mathrm{R}^{2}=0.83$ ) explained $83 \%$ of the variance. The validation of the empirical algorithm, using co-located and coincident satellite and in situ measurements, showed good results with a low mean absolute error $(14.60 \%)$ and a small and positive bias $(3.04 \%)$, indicating that the estimated suspended particulate matter values tend to slightly overestimate the field values.
\end{abstract}

Keywords: empirical algorithm; suspended particulate matter; Río de la Plata; in situ measurements; MODIS-Aqua satellite image.

Algoritmo empírico de sensoramiento remoto para recuperar material particulado en suspensión en una gran región estuarial

Resumen: El Río de la Plata es un estuario extenso y somero ubicado aproximadamente a $35^{\circ} \mathrm{S}$ en el Océano Atlántico suroccidental. Es uno de los sistemas más turbios del planeta, transporta una gran cantidad de nutrientes y material particulado en suspensión, tanto orgánico como inorgánico, a las aguas de la plataforma continental adyacente. El conocimiento de la concentración de estos materiales y su variabilidad espacio-temporal son críticos para cualquier estudio biológico en la región. En este trabajo, se estableció empíricamente la relación entre el material particulado en suspensión y la turbidez, a fin de obtener distribuciones espaciales de material particulado en suspensión a partir de datos satelitales (Aqua-MODIS). Se encontró una fuerte correlación entre el material particulado en suspensión y la turbidez (coeficiente de correlación de Pearson $=0.91$ ) y la regresión lineal obtenida (pendiente $=0.76$ ordenada al origen $=12.78, \mathrm{R}^{2}=0.83$ ) explicó el $83 \%$ de la variación de los datos. La validación, utilizando mediciones satelitales y datos in situ coincidentes, mostró buenos resultados con un bajo error absoluto medio $(14.60 \%)$ y un sesgo pequeño y positivo (3.04\%), lo que indicó que los valores de material particulado en suspensión estimados tienden a sobrestimar ligeramente los valores de campo.

Palabras clave: algoritmo empírico; material particulado en suspensión; Río de la Plata; medidas in situ; imágenes satelitales Aqua-MODIS.

Citation/Como citar este artículo: Camiolo M.D., Cozzolino E., Dogliotti A.I., Simionato C.G., Lasta C.A. 2019. An empirical remote sensing algorithm for retrieving total suspended matter in a large estuarine region. Sci. Mar. 83(1): 53-60 https://doi.org/10.3989/scimar.04847.22A

Editor: P. Puig.

Received: August 27, 2018. Accepted: January 10, 2019. Published: March 4, 2019.

Copyright: () 2019 CSIC. This is an open-access article distributed under the terms of the Creative Commons Attribution 4.0 International (CC BY 4.0) License. 


\section{INTRODUCTION}

During the last few decades, the effects of suspended particulate matter (SPM) in estuarine and coastal systems have been intensively studied worldwide (Ruddick et al. 2003). These effects are associated with the environmental isolation of fishes, which is advantageous for the survival and growth of juveniles since SPM provides protection against avian predation, reduces intra-specific predation (Blaber and Cyrus 1983) and sometimes increases feeding success due to the particles suspended in the water (Whitfield 1999). Other less favourable aspects are related to an increase in water temperature, which reduces the concentration of dissolved oxygen (Davenport and Sayer 1993). In addition, SPM determines the depth that light penetrates into the water column, thus influencing primary production (Carreto et al. 1986). Negative effects on the density of many invertebrates (Shaw and Richardson 2001) have also been reported. Finally, SPM can carry metals (Bazán and Janiot 1991) that are directly related to toxicity in the food web (Gerritsen et al. 2001). SPM is quantified as the mass per unit volume or concentration of organic and inorganic matter present in the body of water (Gohin et al. 2005). SPM is typically composed of fine particles with diameters of less than $63 \mu \mathrm{m}$ (Eisma and Kalf 1979). Turbidity, as defined by the International Standards Organization ISO 7027 (ISO 1999), is an optical property which is highly correlated and can be used as a proxy to SPM concentration (Murillo 2009).

Remote sensing provides a comprehensive and synoptic view of the oceans (Hooker and McClain 2000), which has shown to be useful for mapping surface SPM concentrations. A number of studies have used satellite-derived reflectance to analyse the spatial extent and temporal changes of SPM in estuaries, lakes, rivers and coastal waters by determining the relationship between this parameter and reflectance (e.g. Walker and Hammack 2000, Doxaran et al. 2009). In addition, many authors have found linear relationships between SPM and turbidity in coastal environments (e.g. Marquis 2005, Packman et al. 1999).

The Río de la Plata (RdlP) carries high amounts of nutrients and organic and inorganic SPM to the adjacent shelf waters (Bazán and Janiot 1991) and is considered among the most turbid systems in the world (Framiñan and Brown 1996). The RdlP estuarine turbidity maximum zone plays an important role in the life history of estuarine fish species (Jaureguizar et al. 2003, 2016), zooplankton (Berasategui et al. 2006) and benthos (Giberto 2008). Variations in the RdlP discharge have a strong effect on the upstream/downstream displacement of the estuarine turbidity maximum zone (Jaureguizar et al. 2016) that ultimately affects different aspects of the RdlP's ecosystem (sediment transport, life cycle, fishing, boating, dredging and pollution control), with major economic consequences. Therefore, the knowledge of the surface concentration of SPM and its spatial and temporal variability would provide valuable data for operational planning in the RdlP estuarine region.
In a previous study the SPM distribution in the RdlP derived from MODIS-Aqua images using the OC5 empiric algorithm was analysed (Moreira et al. 2013). The OC5 algorithm developed by IFREMER for the Bay of Biscay (Gohin et al. 2002, 2005) showed a poor performance in the turbid waters of the RdlP estuarine region (Camiolo et al. 2016). The poor efficiency is mainly associated with the use of NASA standard atmospheric correction and with the semiempirical nature of the proposed algorithm, which could be sensitive to changes in water composition and would therefore only have regional validity (Camiolo et al. 2016, Dogliotti et al. 2016). It has been previously shown that the standard atmospheric correction completely fails to retrieve water reflectance in most of the RdlP's turbid waters, mainly due to sensor saturation in the bands 667, 748 and $869 \mathrm{~nm}$ used for the atmospheric correction and to incorrect estimation of the marine contribution in the near infrared in these extremely turbid waters (Dogliotti et al. 2011). For this reason, the aim of the present study was to obtain an empirical relationship between field SPM and turbidity data in the RdlP estuarine region that would allow SPM maps to be obtained from remote sensing data.

\section{MATERIALS AND METHODS}

\section{Study area}

The RdlP, located at approximately $35^{\circ} \mathrm{S}$ on the eastern coast of southern South America (Fig. 1), carries high amount of nutrients and suspended particulate and dissolved organic matter to the adjacent shelf waters (Bazán and Janiot 1991). The RdlP has an average discharge of $22000 \mathrm{~m}^{3} \mathrm{~s}^{-1}$, and peaks as high as 90000 $\mathrm{m}^{3} \mathrm{~s}^{-1}$ and as low as $7800 \mathrm{~m}^{3} \mathrm{~s}^{-1}$ have been observed in association with the cycles of El Niño-Southern Oscillation (Jaime et al. 2002). The sediments that reach the estuary come mainly from the Paraná river and the drainage of a number of minor tributaries along the Ar-

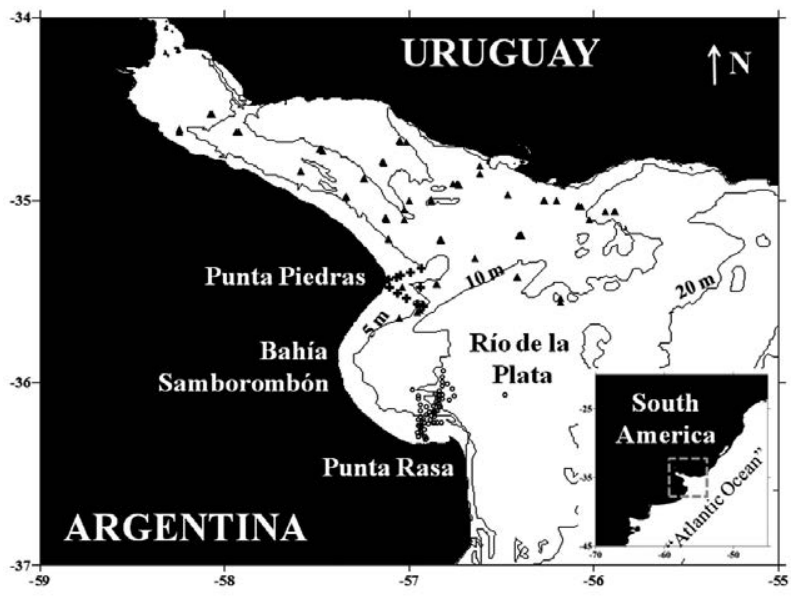

Fig. 1. - Location of the stations used to determine the relationship between SPM and turbidity. Samples were collected during six cruises in the mid-estuary during research cruise FREPLATAFFEM (triangles), two research cruises in Punta Piedras (crosses) and seven research cruises in Punta Rasa (circles). 
Table 1. - Number of samples collected between 2010 and 2014, used to find the relation between a) in situ SPM and in situ turbidity, and b) in situ vs satellite-derived (sat) SPM. (x) Only turbidity data were measured. (*) HORIBA U-22XD turbidimeter. (+) HACH 2100P ISO turbidimeter. RdlP: Río de la Plata.

\begin{tabular}{|c|c|c|c|c|}
\hline Cruise & Date & $\begin{array}{l}\text { SPM "in situ" vs } \\
\text { turbidity "in situ" }\end{array}$ & $\begin{array}{l}\text { SPM "in situ" } \\
\text { vs SPM sat. }\end{array}$ & Total \\
\hline PR01(*) & $24 / 11 / 2010$ & 11 & & 11 \\
\hline $\mathrm{PR} 02(*)$ & $24 / 12 / 2010$ & 4 & 8 & 12 \\
\hline PR03(*) & $24 / 2 / 2011$ & 8 & & 8 \\
\hline PR04(*) & $22 / 3 / 2011$ & 9 & & 9 \\
\hline PR05(*) & $24 / 4 / 2011$ & 11 & & 11 \\
\hline PR06(+) & $15 / 5 / 2012$ & 5 & 8 & 13 \\
\hline PP01(+) & $27 / 2 / 2013$ & 7 & 4 & 11 \\
\hline $\mathrm{PP} 02(*)$ & $30 / 4 / 2013$ & 9 & 2 & 11 \\
\hline $\operatorname{PR07}(*,+)$ & $22 / 11 / 2014$ & 3 & 5 & 8 \\
\hline PR08(*, +) & $17 / 12 / 2014$ & & & $9(\mathrm{x})$ \\
\hline FREPLATA-FFEM-1(+) & 23 to $28 / 11 / 2009$ & 21 & 5 & 26 \\
\hline FREPLATA-FFEM-2(+) & 17 to $19 / 3 / 2010$ & 26 & & 26 \\
\hline FREPLATA-FFEM-3(+) & 23 to $25 / 6 / 2010$ & 26 & & 26 \\
\hline FREPLATA-FFEM-4(+) & 23 to $27 / 8 / 2010$ & 26 & & 26 \\
\hline FREPLATA-FFEM-5(+) & 25 to $28 / 10 / 2010$ & 26 & & 26 \\
\hline FREPLATA-FFEM-6(+) & 15 to $17 / 12 / 2010$ & 26 & & 26 \\
\hline PWC 2012 & 20 to $25 / 6 / 2012$ & & 9 & 9 \\
\hline PWC 2013 & 17 to $18 / 5 / 2013$ & & 7 & 7 \\
\hline PWC 2014 & 19 to $23 / 6 / 2014$ & & 9 & 9 \\
\hline
\end{tabular}

gentinean coast (Framiñan et al. 1999). The amount of sediments transported by the RdlP has been estimated to range between 80 and 160 million $\mathrm{t}^{-1}$ (Simionato et al. 2011a). With mean concentrations of total suspended matter ranging from 100 to $300 \mathrm{mg} \mathrm{l}^{-1}$ and up to $400 \mathrm{mg} \mathrm{l}^{-1}$ (Framiñan and Brown 1996), like the Amazonas (200 $\left.\mathrm{mg} \mathrm{l}^{-1}\right)$, Mississippi (362 $\mathrm{mg} \mathrm{l}^{-1}$ ) and Guadalquivir (600 $\mathrm{mg} \mathrm{l}^{-1}$ ) (Ruiz et al. 2015), this estuary is one of the most turbid in the world.

\section{In situ data}

The calibration of the empirical algorithm for the RdlP region was carried out using field data of SPM concentration $\left(\mathrm{mg} \mathrm{l}^{-1}\right)$ and turbidity (formazin nephelometric units, FNU). Data were collected simultaneously at the surface at 218 stations during a) six cruises in the mid-estuary performed in the research cruise FREPLATA-FFEM (2009-2010, 151 stations, triangles); b) two research cruises (2013, 16 stations, crosses) in the Punta Piedras; and c) seven research cruises (2010-2012 and 2014, 51 stations, circles) in the Punta Rasa (Fig. 1, Table 1). In every case, SPM was determined by the gravimetric method. Glass fibre filters (APFF04700, Millipore) which had been previously burned $\left(550^{\circ} \mathrm{C}, 30 \mathrm{~min}\right)$ were weighed. The water samples were filtered, and the filters were dried at $100^{\circ} \mathrm{C}$ for $24 \mathrm{~h}$ (American Public Health Association 1992) and weighed again. Water samples gathered during the Punta Piedras and Punta Rasa cruises were analysed at the Laboratorio de Biología Molecular y Microbiología of the Instituto Nacional de Investigación y Desarrollo Pesquero (INIDEP). Water samples collected during the FREPLATA-FFEM research cruise were processed in the Laboratorio de Química Marina of the Servicio de Hidrografía Naval Argentina. Water samples for turbidity determination were analysed on board. In the FREPLATA-FFEM research cruise and the Punta Piedras cruises 01 and 02 a portable HACH $2100 \mathrm{P}$ ISO turbidimeter was used, whereas in the Punta

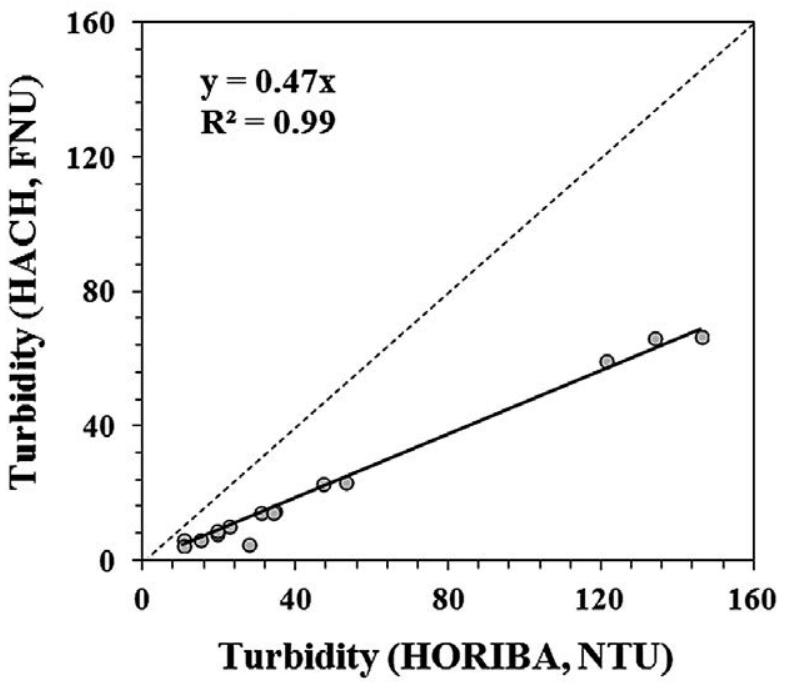

Fig. 2. - Linear relationship between simultaneous measurements of turbidity using HACH 2100P ISO (formazin nephelometric unit, FNU) and HORIBA U-22XD (nephelometric turbidity unit, NTU) turbidimeters.

Rasa cruises 01 to 06 a portable HORIBA U-22XD turbidimeter was used instead. A comparison between measurements collected simultaneously using $\mathrm{HACH}$ 2100P ISO and HORIBA U-22XD sensors during two cruises performed in Punta Rasa (07/08) is shown in Figure 2. A high correlation was found between the estimates [squared correlation coefficient $\left(\mathrm{R}^{2}\right)=0.99$ ]. A linear relationship was then fitted to the data and used to obtain HACH 2100P ISO-like measurements from the HORIBA U-22XD data.

For the statistical analysis of the in situ SPM vs in situ turbidity data, the Pearson correlation coefficient (PCC) (Eq. 1) was used, according to the formula:

PCC $=\frac{\text { cov. variable in situ and variable in situ data }}{\text { sd. variable in situ } \times \text { variable in situ data }}$

where cov. is the covariance, sd. is the standard deviation and the variable is in situ turbidity, in situ SPM or 
Table 2. - AT and C (FNU) coefficient calibration for the bands 645 and $859 \mathrm{~nm}$ MODIS-Aqua. Dogliotti et al. (2011).

\begin{tabular}{ccc}
\hline$\lambda(\mathrm{nm})$ & AT & C \\
\hline 645 & 228.1 & 0.1641 \\
859 & 3078.9 & 0.2112 \\
\hline
\end{tabular}

satellite SPM. Before pooling of the data from all the cruises, an ANCOVA analysis was used to compare the regression equations from the three sets of regression data (research cruises FREPLATA-FFEM, Punta Piedras and Punta Rasa, Fig. 1).

\section{Validation of satellite SPM estimates}

The empirical method for SPM was validated following the methodology of matching satellite and field data suggested by Bailey and Werdell (2006). A \pm 5 -h temporal window between the satellite overpass and the in situ measurements (due to the presence of clouds it could not be shortened) and a spatial box of $3 \times 3$ pixels were used. As a test of homogeneity, and to minimize the impact of the variability of the geophysical variable in the satellite pixel box, the coefficient of variation $(\mathrm{CV})$, defined as the ratio between the standard deviation and the average, was used. A limit of $\mathrm{CV}=0.2$ was chosen, thus excluding all satellite boxes showing CV values larger than 0.2. Level 1A MODIS-Aqua images (1.1 km spatial resolution) were downloaded from the NASA ocean colour website (https://oceancolor.gsfc. nasa.gov/). Images were processed using the freely available SeaDAS 7.02 software to obtain remotely sensed reflectance $\left(\mathrm{R}_{\mathrm{rs}}\right)$ using the NIR-SWIR switching atmospheric correction algorithm (Wang 2007, Wang and Shi 2007) and masking clouds using the $2130 \mathrm{~nm}$ band and a threshold of 0.018. The SPM images were obtained by applying the regional calibration algorithm for the RdlP to MODIS-Aqua turbidity images previously obtained by applying the semi-analytic algorithm developed by Dogliotti et al (2015), according to Equation (2):

$$
\text { turbidity }=\frac{\mathrm{AT}^{\lambda} \rho_{w}(\lambda)}{\left(1-\frac{\rho_{w}(\lambda)}{\mathrm{C}^{\lambda}}\right)}(\mathrm{FNU})
$$

where the AT y C calibration coefficients are dependent on the wavelength, $\lambda$ (Table 2) and $\rho_{\mathrm{w}}$ is the water reflectance that was calculated from the remote sensing reflectance $\left(\mathrm{R}_{\mathrm{rs}}\right)$ as $\rho_{\mathrm{w}=} \mathrm{R}_{\mathrm{rs}} \pi$. The wavelength used depended on the $\rho_{\mathrm{w}}$ (645) (for more details see Dogliotti et al. 2015).

To perform the match-up analysis, data from 57 stations with SPM measurements collected during 11 cruises between 2010 and 2014 for which cloud-free MODIS-Aqua images were available were used (Fig. 3 , Table 1). Previous to the analysis, both satellite and field data were log-transformed to improve the distribution of errors and because bio-optical data have a log-normal distribution (Campbell 1995). For the statistical analysis of the relationship between in situ SPM vs satellite SPM data, the PCC (Eq. 1), the mean absolute error (Eq. 3) (MAE) and the bias (Eq. 4) were used, according to the following formulae:

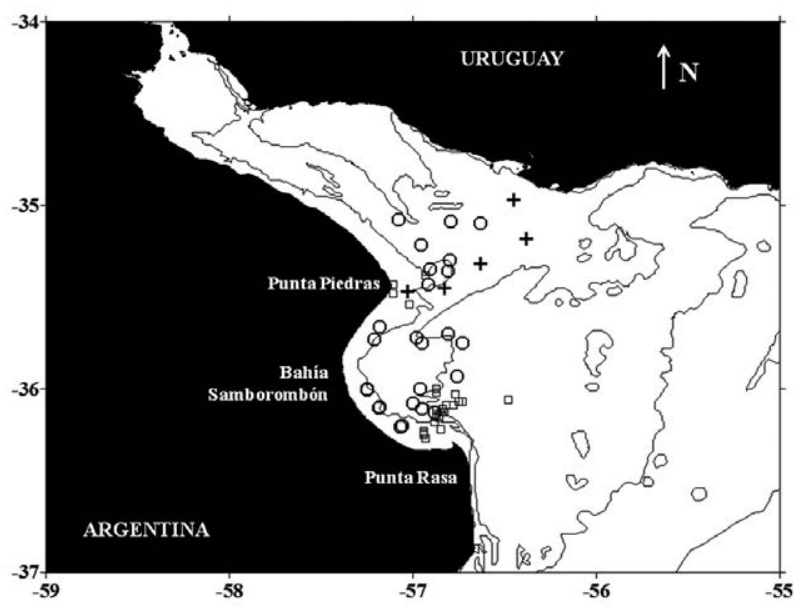

Fig. 3. - Location of the stations used for validation of satellitederived estimates of SPM $\left(\mathrm{mg}^{-1}\right)$ during the research cruises: PWC2012, PWC2013 and PWC2014 (open circles), Punta Rasa 02, 06 and 07, Punta Piedras 01 and 02 (open squares) and FREPLATAFFEM (crosses).

MAE $=\frac{\sum[\log \text { satellite data }-\log \text { in situ data }]}{\mathrm{n}} 100$

bias $=\frac{\sum[\log \text { satellite data }-\log \text { in situ data }]}{\mathrm{n}} 100$

where $\mathrm{n}$ is the number of comparisons made.

\section{RESULTS}

\section{Calibration of SPM vs turbidity relationship}

The ANCOVA analysis showed that the three in situ data sets (FREPLATA-FFEM, Punta Piedras and Punta Rasa) had no significant statistical differences in the slope $(\mathrm{F}=1.3846, \mathrm{p}=0.2531)$ and the intercepts only showed no significant differences between Punta Rasa and FREPLATA-FFEM $(\mathrm{F}=11.17, \mathrm{p}<0.0001)$. Considering that the slopes for all the sites were not significantly different, and that for most of the places the intercepts were not significantly different, only one slope (0.76) and intercepts (12.78) were calculated for all data. The relationship between in situ SPM and in situ turbidity observations showed a good linear correlation with an $\mathrm{R}^{2}$ of 0.83 (Fig. 4). The equation of the correlation line (solid line) represents the regional empirical algorithm. The PCC was 0.91, indicating a good relationship between the two variables.

\section{Validation of satellite-derived SPM values}

Of the 57 stations used for the validation (Fig. 3), only 22 remained valid after the spatial and temporal criteria for the match-up analysis had been applied (Fig. 5). Figure 6 displays a scatter plot of the satellitederived SPM estimated using the combined semianalytic algorithm to retrieve turbidity and the regional empirical relationship found in this study vs in situ 

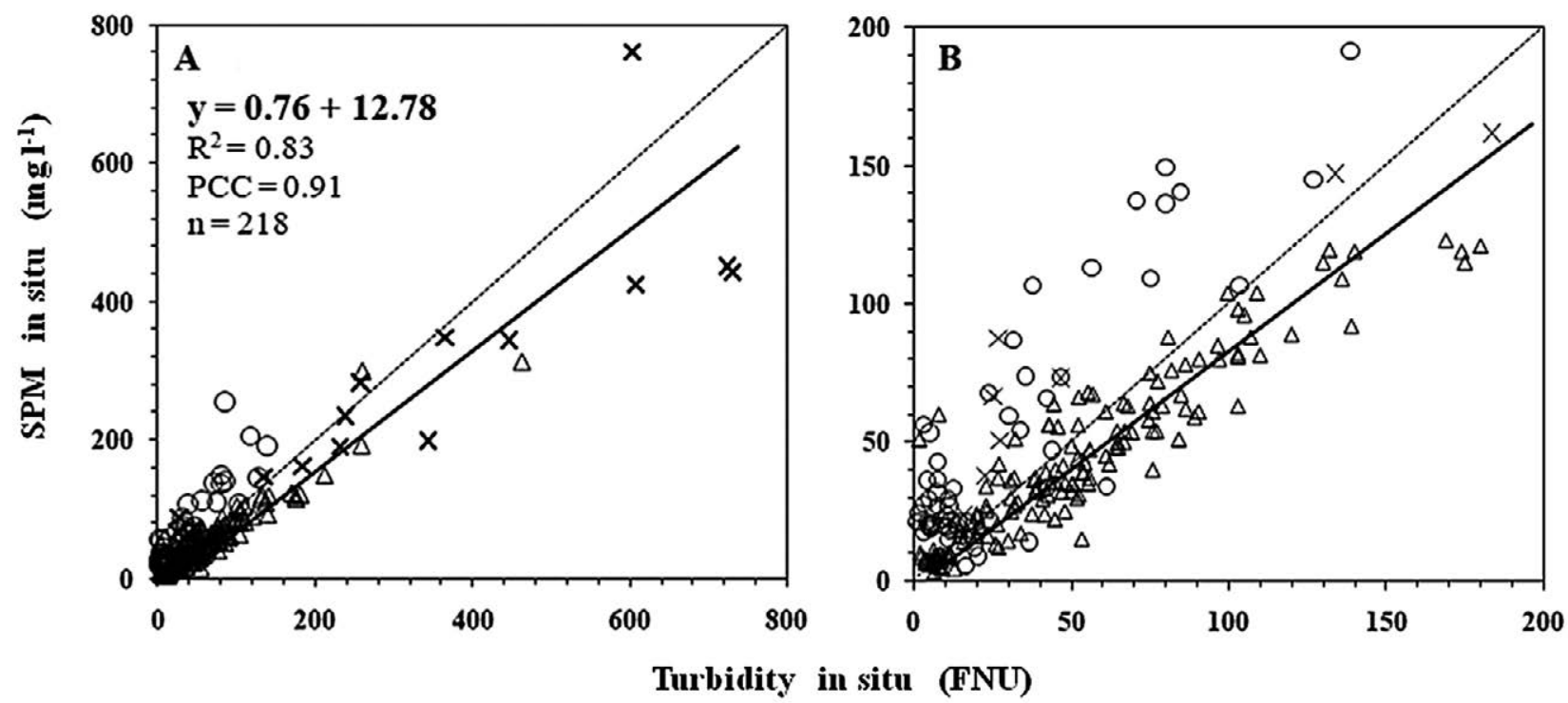

Fig. 4. - A, scatter plot of SPM vs turbidity for the Río de la Plata region. Data corresponding to research cruise FREPLATA-FFEM (triangles), Punta Piedras (crosses) and Punta Rasa (circles) as indicated in Figure 1. B, detail of the SPM vs turbidity at concentrations below 200 $\mathrm{mg} \mathrm{l}^{-1}-\mathrm{FNU}$, respectively. Dotted line: straight $1: 1$.

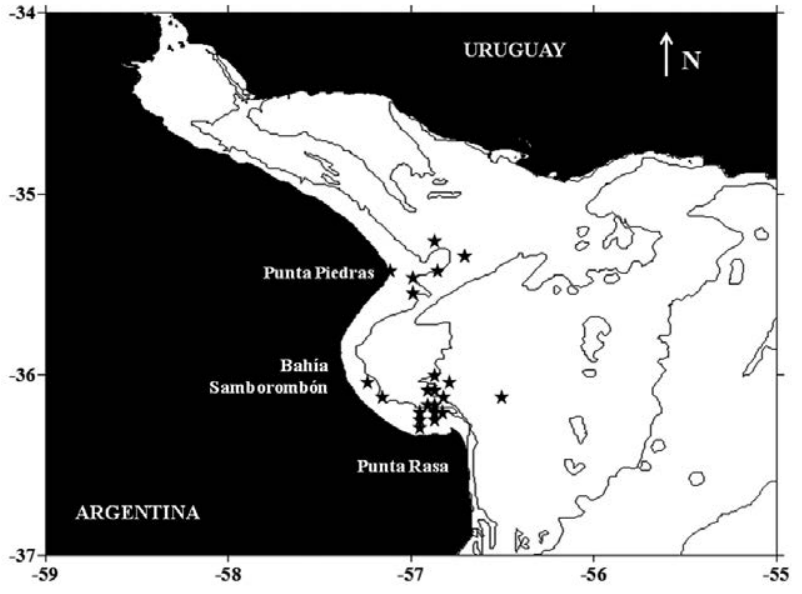

Fig. 5. - Location of the data used for the match-up analysis after applying the spatial and temporal excluding criteria (see the text).

observations. The results show a good linear correlation, with a PCC of 0.78 and an $\mathrm{R}^{2}$ of 0.70 . The MAE $(14.60 \%)$ indicated a relatively low average error in the predicted SPM (Eplee et al. 2001). The bias was small and positive $(3.04 \%)$, not exceeding $10 \%$, indicating that the algorithm tends to slightly overestimate the observed SPM values. The satellite images processed using the combined algorithm for 28 January and 15 February 2006 are shown in Figure 7.

\section{DISCUSSION}

In the present study, a good correlation between in situ SPM and turbidity in the estuarine region of RdlP $\left(\mathrm{R}^{2}=0.83\right)$ was found and, when this empirical relation was applied to satellite-derived turbidity images, good estimates of SPM were obtained $\left(\mathrm{R}^{2}=0.70, \mathrm{PCC}=0.78\right)$. The relationship between SPM and turbidity showed a low dispersion $(\mathrm{MAE}=14.6 \%)$ and the small and

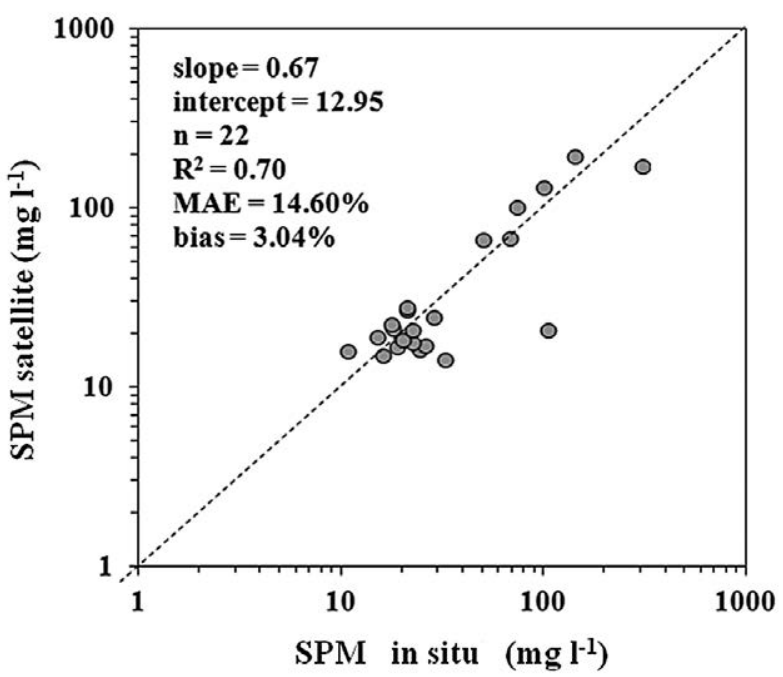

Fig. 6. - Log-log scatter plots of in situ SPM vs satellite-derived SPM using the combined global-regional relationship for Río de la Plata. Dotted line: straight 1:1. Slope, intercept and statistics are shown.

positive bias $(3.04 \%)$ indicated that the estimated SPM values tend to overestimate the field values. The performance of the regional calibration of an empirical algorithm for SPM showed good efficiency, indicating the practical advantage of using relatively inexpensive and portable nephelometers and SPM analysis to retrieve satellite-derived SPM maps, as suggested in Dogliotti et al. (2015), in regions with high spatial and temporal variability such as the RdlP estuarine region.

The relationship between SPM and turbidity showed differences around the world (e.g. Packman et al. 1999, Marquis 2005), mainly caused by differences in the particle type (size and composition). In the estuarine region of the RdlP, the surface particle size distribution is heterogeneous, with mainly silt and clay in the upper and middle area (research cruise FREPLATA-FFEM) (Simionato et al. 2011b), and 

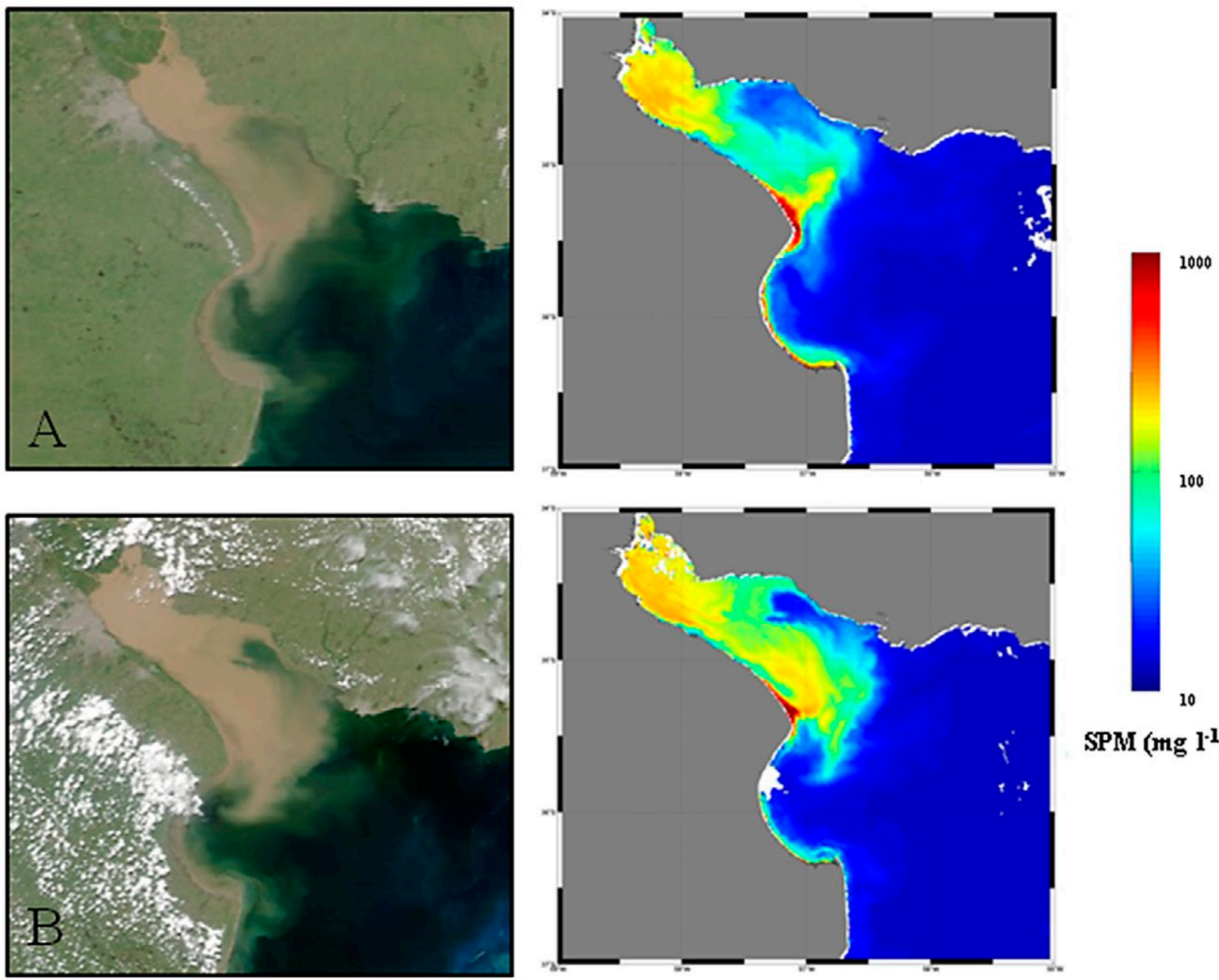

100

Fig. 7. - MODIS-Aqua Quasi-True-Colour (left panel) and SPM concentration map (right panel) for the Río de la Plata region. Days: January 28 (A) and February 15 (B), 2006.

silt and sand in the outer region (Punta Rasa, research cruises 01, 02, 03, 04, 05, 06 and 07), where silt is mainly associated with nearshore areas, while the sand can be found in deeper water influenced by the coastal drift (Ottmann and Urien 1965, Lorenzo et al. 2006) (Fig. 4B). Despite the particle size differences in these two regions, the empirical relationship between in situ SPM and turbidity in the sampled regions of the RdlP (FREPLATA-FFEM, Punta Piedras and Punta Rasa) showed no significant differences in the slope and in most of the intercepts. There is therefore no reason to believe that the study area has to be treated by regions by applying an empirical method for SPM vs turbidity. The lack of differences within this large, shallow and microtidal estuarine region $\left(32000 \mathrm{~km}^{2}\right)$ could be associated with its high sensitivity to wind variability on a synoptic timescale. The estuary rapidly responds to wind variability (around 4 days) in both, currents and salinity fields, and the mean seasonal conditions are characterized by a very large dispersion (Simionato et al. 2007, Meccia et al. 2013). Given the great wind variability (Simionato et al. 2005) and the sharp changes in the freshwater discharge observed in the RdlP, which cause large upstream or downstream movement in the location of the surface fronts (Jaureguizar et al. 2016), the SPM distribution will vary greatly, explaining the lack of significant differences along the entire estuarine region. Similarly, the differences in the intercept observed between FREPLATA-FFEM and Punta Rasa could be associated more with the composition of sediments than with the instruments used, since Punta Piedras and Punta Rasa had no significant differences but the synoptic timescale of variability in the distribution of surface sediment prevented their differentiation.

Part of the observed differences between satellitederived and field SPM measurements might be caused by the atmospheric signal, which might not have been completely removed when the turbidity images were processed (Dogliotti et al. 2011, 2015). A match-up analysis using in situ water reflectance measurements is needed to evaluate the performance of existing atmospheric correction algorithms in these highly turbid waters. One of the main challenges in using ocean colour imagery is to determine the degree of correlation between the in situ measurements and the satellitederived data. In this type of match-up analysis, a correlation of $85 \%$ (or $15 \%$ error) is considered a very good fit (Gregg and Casey 2004, Djavidnia et al. 2006), 
so the result obtained based on $40 \%$ of the available data was very good (Fig. 3). The reduced number of samples used in the match-up analysis $(n=22$ of $n=57$ available) was caused by the strict protocol used and the amount of cloud-covered satellite images present for those dates.

The present results demonstrate the advantage of using a general algorithm to retrieve turbidity from remotely sensed data and then to apply a regional relationship (turbidity vs SPM) to finally obtain SPM maps in a relatively easy and cheap way, i.e. without in situ reflectance measurements, as suggested in Dogliotti et al. (2015). Nevertheless, some differences between satellite-derived and in situ SPM data still remain, partly due to differences in sediment type (particle size and composition) in different parts of the study area as is suggested by the spread of the data in the field SPM vs turbidity relationship found in this study. The analysis of local differences of these relationships, through the analysis of the sediment type (size and composition), and how this might influence satellite-derived SPM values, deserve further analysis and will be the topic of a future study.

\section{ACKNOWLEDGEMENTS}

This study is a contribution to the ANPCyT project PICT 2010-1831. Martina Camiolo's participation was possible thanks to an ANPCyT doctoral fellowship in the framework of this project. María Constanza Hozbor is thanked for her help in processing the water samples. This study is INIDEP contribution number 2152 .

\section{REFERENCES}

American Public Health Association (APHA). 1992. Standard methods for the examination of water and wastewater. APHA, AWWA, WPCF, Washington D.C., pp. 9-73.

Bailey S., Werdell P. 2006. A multi-sensor approach for the on orbit validation of ocean color satellite data products. Remote Sens. Environ. 102: 12-23.

https://doi.org/10.1016/j.rse.2006.01.015

Bazán J.M., Janiot L.J. 1991. Zona de máxima turbidez y su relación con otros parámetros del Río de la Plata. Doc. Téc. Dto. Oceanogr. Serv. Hidrog. Naval 65: 1-22.

Berasategui A.D., Menu Marque S., Gomez Erache M., et al. 2006. Copepod assemblages in a highly complex hydrographic region. Estuar. Coast. Mar. Sci. 66: 483-492. https://doi.org/10.1016/j.ecss.2005.09.014

Blaber S.J.M., Cyrus D.P. 1983. The biology of carangidae (Teleostei) in Natal estuaries. J. Fish. Biol. 22: 173-188. https://doi.org/10.1111/j.1095-8649.1983.tb04738.x

Camiolo M.D., Cozzolino E., Simionato C.G., et al. 2016. Evaluating the performance of the OC5 algorithm of IFREMER for the highly turbid waters of Río de la Plata. Braz. J. Oceanogr. 64: 19-28. https://doi.org/10.1590/S1679-87592016098506401

Campbell J.W. 1995. The lognormal distribution as a model for bio-optical variability in the sea. J. Geophys. Res. 100: $13237-13254$. https://doi.org/10.1029/95JC00458

Carreto I., Negri R., Benavides H. 1986. Algunas características del florecimiento del fitoplancton en el frente del Río de la Plata. Rev. Inv. Des. Pesq. 5: 7-29.

Davenport J., Sayer M. 1993. Physiological determinants of distribution of fish. J. Fish. Biol. 43: 121-145.

Djavidnia S., Mélin F., Hoepffner N. 2006. Analysis of Multi-Sensor Global and Regional Ocean Colour Products. MERSEA-IP Marine Environment and Security for the European AreaIntegrated Project Report on Deliverable D.2.3.5 European
Commission-Joint Research Centre Ref: MERSEA-WP02JRC-STR-0001-01A, 228 pp.

Dogliotti A.I., Ruddick K., Nechad B., et al. 2011. Improving water reflectance retrieval from MODIS imagery in the highly turbid waters of La Plata River. Proceed. VI Int. Conf. Current problems in optics of natural water, ONW'2011, St. Petersburg, Russia, 8 pp. http://www.vliz.be/en/imis?module=ref\&refid=221469

Dogliotti A.I., Ruddick K.G., Nechad B., et al. 2015. A single algorithm be used to retrieve turbidity from remotely-sensed data in all coastal and estuarine waters. Remote Sens. Environ. 156: $157-168$. https://doi.org/10.1016/j.rse.2014.09.020

Dogliotti A.I., Ruddick K., Guerrero R. 2016. Seasonal and interannual turbidity variability in the Río de la Plata from 15 years of MODIS: El Niño dilution effect. Est. Coast. Shelf. Sci. 182: 27-39. https://doi.org/10.1016/j.ecss.2016.09.013

Doxaran D., Froidefond J.M., Castaing P., et al. 2009. Dynamics of the turbidity maximum zone in a macrotidal estuary (the Gironde, France): Observations from field and MODIS satellite data. Est. Coast. Shelf. Sci. 81: 321-332. https://doi.org/10.1016/j.ecss.2008.11.013

Eisma D., Kalf J. 1979. Distribution and particle size of suspended matter in the southern bight of the North Sea and the Eastern Channel. J. Sea. Res. 13: 298-324. https://doi.org/10.1016/0077-7579(79)90008-5

Eplee R.E., Robinson W.D., Bailey S.W., et al. 2001. Calibration of SeaWiFS. II. Vicarious Techniques. Appl Opt. 40: 6701-6718. https://doi.org/10.1364/AO.40.006701

Framiñan M., Brown O. 1996. Study of the Río de la Plata turbidity front, part I: spatial and temporal distribution. Cont. Shelf. Res. 16: $1259-1282$ https://doi.org/10.1016/0278-4343(95)00071-2

Framiñan M., Etala M.P., Acha M., et al. 1999. Physical characteristics and processes of the Río de la Plata Estuary. In: Perillo G.M., Piccolo M.C., Pino Quivira M. (eds). Estuaries of South America: Their Morphology and Dynamics. Springer. pp. 161-194. https://doi.org/10.1007/978-3-642-60131-6_8

Gerritsen H., Boon J., van der Kaaij T., et al. 2001. Integrated Modelling of Suspended Matter in the North Sea. Estuar. Coast. Shelf. Sci. 53: 581-594. https://doi.org/10.1006/ecss.2000.0633

Giberto D.A. 2008. Estructura de la comunidad bentónica y ecología trófica de Scianeidae (Pisces: Osteichthyes) en el estuario del Río de la Plata. Comahue, Argentina, Universidad Nacional del Comahue, Ph.D. thesis 228 pp.

Gohin F., Druon J.N., Lampert L. 2002. A five channel chlorophyll concentration algorithm applied to SeaWIFS data processed by SeaDAS in coastal waters. Int. J. Remote Sens. 23: 1639-1661. https://doi.org/10.1080/01431160110071879

Gohin F., Loyer S., Lunven M., et al. 2005. Satellite-derived parameters for biological modelling in coastal waters: Illustration over the eastern continental shelf of the Bay of Biscay. Remote Sens. Environ. 95: 29-46. https://doi.org/10.1016/i.rse.2004.11.007

Gregg W.W., Casey N.W. 2004. Global and regional evaluation of the SeaWiFS chlorophyll data set. Remote Sens. Environ. 93: 463-479. https://doi.org/10.1016/j.rse.2003.12.012

Hooker S.B., McClain C.R. 2000. The calibration and validation of SeaWiFS data. Prog. Oceanogr. 45: 427-465 https://doi.org/10.1016/S0079-6611(00)00012-4

International Organization for Standardization (ISO). 1999. Water quality-Determination of turbidity. ISO 7027. $18 \mathrm{pp}$.

Jaime P., Menéndez A., Uriburu Quirno M., et al. 2002. Análisis del régimen hidrológico de los ríos Paraná y Uruguay. Informe LHA 05-216-02. I.N.A., Buenos Aires, 140 pp.

Jaureguizar A.J., Menni R., Bremec C., et al. 2003. Fish assemblage and environmental patterns in the Río de la Plata estuary. Estuar. Coast. Shelf Sci. 56: 921-933. https://doi.org/10.1016/S0272-7714(02)00288-3

Jaureguizar A.J., Solari A., Cortés F., et al. 2016. Fish diversity in the Río de la Plata and adjacent waters: an overview of environmental influences on its spatial and temporal structure. J. Fish Biol. 89: 569-600. https://doi.org/10.1111/jfb.12975

Lorenzo E., Fossati M., Bellón D., et al. 2006. Proyecto PDTModelación hidrosedimentológica del Río de la Plata, 233 pp. 
Marquis P. 2005. Turbidity and Suspended Sediment as Measures of Water Quality. Watershed Manag. Bull. 9: 21-23.

Meccia V.L., Simionato C.G., Guerrero R. 2013. The Río de la Plata estuary response to wind variability in synoptic time scale: $\mathrm{Sa}$ linity fields and breakdown and reconstruction of the salt wedge structure. J. Coas. Res. 29: 61-77. https://doi.org/10.2112/JCOASTRES-D-11-00063.1

Moreira D., Simionato C.G., Gohin F., et al. 2013. Suspended matter mean distribution and seasonal cycle in The Río de la Plata estuary and the adjacent from ocean color satellite (MODIS) and in-situ observations. Cont. Shelf Res. 68: 51-66. https://doi.org/10.1016/j.csr.2013.08.015

Murillo J.M. 2009. Turbidez y sólidos en suspensión de las aguas de escorrentía susceptibles de ser utilizadas en la recarga artificial del acuífero granular profundo subyacente a la ciudad de San Luis de Potosí (México). Bol. Geol. Min. 120: 169-184.

Ottmann F., Urien C. 1965. Observaciones preliminares sobre la distribución de los sedimentos finos en la zona externa del Río de la Plata. Acad. Bras. Cienc. 37: 279-289.

Packman J.J., Comings K.J., Booth D.B. 1999. Using turbidity to determine total suspended solids in urbanizing streams in the Puget Lowlands. Confronting Uncertainty: Managing Change in Water Resources and the Environment. Canad. Water Res. Assoc. Ann. Meet. Vancouver, BC 27-29: 158-165.

Ruddick K., Park Y., Nechad B. 2003. MERIS imagery of Belgian coastal waters: mapping of suspended particulate matter and chlorophyll- $a$. Proc. MERIS user workshop, 1-13th November 2003 (pp. SP-549), Frascati, European Space Agency (ESA).

Ruiz J., Polo M.J., Díez-Minguito M., et al. 2015. The Guadalquivir estuary: a hot spot for environmental and human conflicts. Environmental management and governance. Adv. Coast. Mar. Res. 472: 199-232.

Shaw E.A., Richardson J.S. 2001. Direct and indirect effects of sediment pulse duration on stream invertebrate assemblages and rainbow trout (Oncorhynchus mykiss) growth and survival. Can. J Fish. Aquat. Sci. 58: 2213-2221. https://doi.org/10.1139/f01-160

Simionato C.G., Vera C.S., Siegismund F. 2005. Surface wind variability on seasonal and interannual scales over Río de la Plata area. J. Coast. Res. 21: 770-783. https://doi.org/10.2112/008-NIS.1

Simionato C.G., Meccia V.L., Guerrero R., et al. 2007. Río de la Plata estuary response to wind variability in synoptic to intraseasonal scales: 2. Currents' vertical structure and its implications for the salt wedge structure. J. Geophys. Res. 112: C07005. https://doi.org/10.1029/2006JC003815

Simionato C.G., Moreira D., Re M., et al. 2011a. Estudio de la dinámica hidro-sedimentológica del Río de la Plata: observación y modelación numérica de los sedimentos finos. Proyecto Freplata RLA 99/G31

https://www.ina.gov.ar/legacy/pdf/manual-PHC-FFEM manual_freplata.pdf

Simionato C.G., Moreira D., Piedra Cueva I., et al. 2011b. Proyecto FREPLATA-FFEM Modelado numérico y mediciones in-situ y remotas de las transferencias de sedimentos finos a través del Río de la Plata. Parte A: Adquisición de Datos. Frente Marítimo 1015-323322: 109-136.

Walker N.D., Hammack A. 2000. Impacts of Winter Storms on Circulation and Sediment Transport: Atchafalaya-Vermilion Bay Region, Louisiana. J. Coast. Res. 16: 996-1010.

Wang M. 2007. Remote sensing of the ocean contributions from ultraviolet to near infrared using the shortwave infrared bands: simulations. Appl. Opt. 46: 1535-1547. https://doi.org/10.1364/AO.46.001535

Wang M., Shi W. 2007. The NIR-SWIR combined atmospheric correction approach for MODIS ocean color data processing. Opt. Express 15: 15722-15733. https://doi.org/10.1364/OE.15.015722

Whitfield A.K. 1999. Ichthyofaunal assemblages in estuaries: A South African case study. Reviews. Fish Biol. Fish. 9: 151-186. https://doi.org/10.1023/A:1008994405375 